\title{
Massive levothyroxine ingestion in a pediatric patient: case report and discussion
}

\author{
Josephine Ho, BSc, MD, MSc ${ }^{*}$; Renee Jackson, $\mathrm{MD}^{\dagger}$; and David Johnson, $\mathrm{MD}^{*}$
}

\section{ABSTRACT}

We describe the course of a toddler who ingested a massive amount of levothyroxine and review treatment options for such overdoses. A $2 \frac{1}{2}$-year-old boy presented shortly after an ingestion of up to $7.6 \mathrm{mg}$ of levothyroxine (potentially as much as $700 \mu \mathrm{g} / \mathrm{kg}$ ). He was initially asymptomatic, treated with oral charcoal $1 \mathrm{~g} / \mathrm{kg}$, and discharged home from the emergency department after a few hours. He returned approximately 24 hours later with a temperature of $38.5^{\circ} \mathrm{C}$, heart rate of 163 beats per minute, respiratory rate of 30 breaths per minute, and blood pressure of 136/70 $\mathrm{mm} \mathrm{Hg}$. He had a slightly decreased appetite and no signs or symptoms of infection. He was admitted to hospital and treated with oral acetaminophen. The initial free thyroxine $\left(T_{4}\right)$ was $>$ $100 \mathrm{pmol} / \mathrm{L}$ and free triiodothyronine $\left(\mathrm{T}_{3}\right)$ was $35.3 \mathrm{pmol} / \mathrm{L}$. The patient had desquamation of the palms and soles, hair loss, and irritability during the month following the ingestion. Resolution of the elevated free $T_{4}$ occurred by 12 days post-ingestion and normalization of the thyroid-stimulating hormone by 7 weeks post-ingestion. There were no longterm sequelae. Levothyroxine overdose can result in significant complications, including seizures and arrhythmias, both of which should be monitored for. However, as our case illustrates, massive ingestion of levothyroxine in children typically follows a benign course.

\section{RÉSUMÉ}

Nous décrivons le cas d'un jeune enfant ayant ingéré une quantité massive de lévothyroxine et examinons les options de traitement de surdoses de ce genre. Un garçon de $21 / 2$ ans s'est présenté à l'urgence peu de temps après avoir ingéré jusqu'à 7,6 mg de lévothyroxine (potentiellement jusqu'à 700 $\mu \mathrm{g} / \mathrm{kg})$. Au départ, il était asymptomatique. On lui a administré du charbon activé par voie orale $(1 \mathrm{~g} / \mathrm{kg})$, puis on l'a renvoyé chez lui après quelques heures. II s'est présenté de nouveau environ 24 heures plus tard. II avait alors une température de $38,5{ }^{\circ} \mathrm{C}$, une fréquence cardiaque de 163 battements par minute, une fréquence respiratoire de 30 cycles par minute, et une pression artérielle de $136 / 70 \mathrm{mmHg}$. Son appétit avait légèrement diminué et il ne présentait aucun signe ou symptôme d'infection. Il a été hospitalisé et a reçu de l'acétaminophène (oral). La tyroxine (T4) libre initiale était de $>100 \mathrm{pmol} / \mathrm{L}$ et la triiodothyronine (T3) libre était de 35,3 $\mathrm{pmol} / \mathrm{L}$. Une desquamation de la peau de la paume des mains et de la plante des pieds, une perte de cheveux et une irritabilité sont apparues dans le mois suivant l'ingestion. La résolution de la T4 libre élevée s'est produite 12 jours après l'ingestion et la normalisation de l'hormone de stimulation de la thyroïde 7 semaines après l'ingestion. Aucune séquelle à long terme n'a été observée. Une surdose de lévothyroxine peut entraîner des complications graves, y compris des convulsions et des arythmies, qui doivent toutes deux faire l'objet d'une surveillance. Toutefois, comme l'illustre notre cas, l'ingestion massive de lévothyroxine chez les enfants donne habituellement lieu à une évolution bénigne.

Keywords: children, emergency department, levothyroxine, overdose, pediatric, thyroid hormone, treatment

Hypothyroidism is a common condition and is managed with thyroid hormone replacement. In a cross-sectional study involving 25,862 participants, $5.9 \%$ were taking thyroid hormone replacement. ${ }^{1}$ Levothyroxine is available in various coloured tablets and has no noxious taste, making it particularly attractive to young children. Typical doses of levothyroxine range from 2 to $15 \mu \mathrm{g} / \mathrm{kg}$ per day depending on age. ${ }^{2}$

In the 2008 annual report of the American Association of Poison Control Centers' National Poison Data System, 9,006 unique exposures to thyroid preparations were reported, with only 3 cases of a major adverse outcome and no deaths. ${ }^{3}$ Significant levothyroxine ingestions in children have been reported

From the *Faculty of Medicine, University of Calgary, Calgary, AB; and tDivision of Pediatrics, Alberta Children's Hospital, Calgary, AB.

Correspondence to: Dr. Josephine Ho, Division of Pediatric Endocrinology, Alberta Children's Hospital, 2888 Shaganappi Trail NW, Calgary, AB T3B 6A8; josephine.ho@albertahealthservices.ca.

Submitted May 3, 2010; Revised August 18, 2010; Accepted September 10, 2010

This article has been peer reviewed.

(c) Canadian Association of Emergency Physicians 
previously.-12 We report a case of a toddler with a particularly large levothyroxine ingestion and very few clinical findings. Written consent was obtained from the patient's family for publication of this case.

\section{CASE PRESENTATION}

A 2 $1 / 2$-year-old boy presented to the emergency department (ED) with a history of levothyroxine ingestion. Approximately 45 minutes prior to ED presentation, the boy's mother found him on the floor with an empty prescription container for levothyroxine and 53 tablets missing $(200 \mu \mathrm{g} /$ tablet $=10,600 \mu \mathrm{g}$ total $)$. The medication container, which had a childproof top, had been left on a high breakfast bar and the boy had pushed a chair to the counter to reach it. Both parents were cooking in the kitchen and thought he was playing with a rattling toy. It is unclear how the boy managed to open the lid. The child's mother had recently filled the prescription and knew that approximately 83 tablets were in the bottle. Initially, 30 pills were found on the floor, leaving 53 tablets unaccounted for. Later in the day, a further search revealed approximately 15 more tablets in the living room. The exact amount of levothyroxine ingested is uncertain but was calculated to be a maximum of 38 tablets $(7,600 \mu \mathrm{g})$, resulting in a potential dose of as much as $700 \mu \mathrm{g} / \mathrm{kg}$.

On examination, the boy was alert, interactive, and happy. His vital signs were temperature $37.1^{\circ} \mathrm{C}$, heart rate 106 beats per minute, respiratory rate 28 breaths per minute, blood pressure $87 / 60 \mathrm{~mm} \mathrm{Hg}$, and oxygen saturation $99 \%$ on room air. He weighed $11.6 \mathrm{~kg}$, and his physical examination was normal. He was on no regular medications and had no allergies, and his immunizations were up to date. His past medical history was unremarkable aside from one episode of pyelonephritis at 1 year of age. His family history included maternal hypothyroidism.
The poison control centre was contacted and recommended charcoal treatment but no further intervention or investigations. The patient was treated with oral charcoal $1 \mathrm{~g} / \mathrm{kg}$ approximately 1 hour postingestion. He remained asymptomatic and was discharged home from the ED after 3 hours with instructions to return if any new symptoms arose.

Approximately 24 hours after the levothyroxine ingestion, the patient was brought back to the ED after his mother noted that he had tachycardia, fever, irritability, agitation, and increased thirst. His vital signs were: temperature $38.5^{\circ} \mathrm{C}$, heart rate 163 beats per minute, respiratory rate 30 breaths per minute, blood pressure 136/70 $\mathrm{mm} \mathrm{Hg}$, and oxygen saturation on room air $95 \%$. He had a slightly decreased appetite and no signs or symptoms of infection. An electrocardiogram showed sinus tachycardia. The patient's free thyroxine $\left(\mathrm{FT}_{4}\right)$ level was $>100 \mathrm{pmol} / \mathrm{L}$, and his free triiodothyronine $\left(\mathrm{FT}_{3}\right)$ level was $35.3 \mathrm{pmol} / \mathrm{L}$ (Table 1 ). He was admitted to hospital and treated with oral acetaminophen, dosed at $15 \mathrm{mg} / \mathrm{kg}$, for his elevated temperature. No other medications were administered. The patient was discharged from hospital after 1 day. Normalization of the patient's $\mathrm{FT}_{4}$ level occurred by 12 days post-ingestion and normalization of the thyroidstimulating hormone by 7 weeks post-ingestion.

The patient developed desquamation of his palms and soles approximately 10 days after being in the hospital, which persisted for 2 weeks. He also had some hair loss and irritability during the month following the ingestion. No other significant sequelae from the ingestion were seen.

\section{DISCUSSION}

Our case is similar to other reports of massive levothyroxine ingestion (a PubMed literature search conducted using the key terms levothyroxine, ingestion,

Table 1. Laboratory results post-ingestion of levothyroxine

\begin{tabular}{|c|c|c|c|c|}
\hline & Day 1 & Day 3 & Day 12 & Day 54 \\
\hline Test (reference range) & $\begin{array}{l}\text { Second presentation to } \\
\text { ED ( } 24 \mathrm{hr} \text { post-ingestion) }\end{array}$ & $\begin{array}{c}\text { Prior to discharge from } \\
\text { hospital }\end{array}$ & Outpatient & Outpatient \\
\hline Free $T_{4}(10.0-25.0 \mathrm{pmol} / \mathrm{L})$ & $>100.0$ & $>100.0$ & 23.1 & 18.2 \\
\hline Free $T_{3}$ (3.8-6.7 pmol/L) & 35.3 & 26.3 & 7.2 & 6.8 \\
\hline TSH (0.2-6.0 mU/L) & & & 0.02 & 3.98 \\
\hline
\end{tabular}


and overdose), in that the patient had only mild fever and tachycardia. He did not require any supportive therapy beyond acetaminophen for symptom relief. $\mathrm{He}$ did, however, have sequelae that persisted for approximately 1 month post-ingestion. This is in keeping with the half-life of levothyroxine of approximately 7 days. ${ }^{13}$ Although the onset of symptoms can be delayed up to 11 days, our patient developed symptoms 24 hours after his ingestion. ${ }^{13}$

Levothyroxine overdose in children typically follows a benign course. Patients may be asymptomatic or have symptoms including mild fever, tachycardia, hypertension, and irritability. ${ }^{4-6,8,13,14}$ Some cases involving seizures have been reported. ${ }^{12,15}$ In contrast, adults with massive levothyroxine ingestion typically have more severe symptoms, including cardiac arrhythmias, coma, and malignant hyperthermia. ${ }^{16,17}$ Some case reports suggest that adults with underlying comorbidity, including chronic renal failure and cardiac pathology, are more predisposed to develop severe arrhythmias and decreased level of consciousness following levothyroxine ingestion. ${ }^{16}$ However, it is uncertain whether prediction of who is at risk of severe complications among patients who were previously well is possible.

A variety of potential treatments exist for acute levothyroxine ingestion (Table 2). Gastrointestinal decontamination for large ingestions of levothyroxine, in particular the administration of activated charcoal, can decrease systemic absorption if instituted within 1 hour post-ingestion. ${ }^{18}$ Given the typically benign clinical course in otherwise healthy children, asymptomatic children can be monitored at home following gastrointestinal decontamination. In cases with severe symptoms, such as decreased level of consciousness, seizures, arrhythmias, or symptomatic tachycardia, children should be monitored in hospital for cardiac or neurologic instability. Continuous electrocardiographic monitoring may be prudent in patients with cardiac symptoms or

Table 2. Treatment options for levothyroxine ingestion

\begin{tabular}{|c|c|c|}
\hline Treatment & Proposed benefits/actions & Adverse effects \\
\hline Conservative monitoring ${ }^{10,11,18}$ & $\begin{array}{c}\text { Benign clinical course in most cases } \\
\text { Recommended for most cases when patient is asymptomatic or only mildly } \\
\text { symptomatic }\end{array}$ & \\
\hline $\begin{array}{l}\text { Gastrointestinal } \\
\text { decontamination }{ }^{10,11,19,20}(\mathrm{eg}, \\
\left.\text { activated charcoal } 1-2 \mathrm{~g} / \mathrm{kg} \mathrm{PO}^{2}\right)\end{array}$ & $\begin{array}{l}\text { Decreases systemic absorption } \\
\text { Recommended if within } 1 \mathrm{hr} \text { of ingestion }{ }^{20}\end{array}$ & $\begin{array}{l}\text { Nausea/vomiting } \\
\text { Aspiration pneumonia }\end{array}$ \\
\hline $\begin{array}{l}\text { Cholestyramine } \\
\text { divided }(240 \mathrm{mg} / \mathrm{kg} / \mathrm{d} \text { in } 3 \\
\left.\text { doses }{ }^{2}\right)\end{array}$ & $\begin{array}{l}\text { Decreases systemic absorption by binding and enhancing elimination } \\
\text { Consider if ingestion is recent }\end{array}$ & $\begin{array}{l}\text { Nausea/vomiting } \\
\text { Abdominal distention/ } \\
\text { pain }\end{array}$ \\
\hline $\begin{array}{l}\text { Beta-blocker }{ }^{7,13} \text { (eg, propranolol } \\
1-2 \mathrm{mg} / \mathrm{kg} / \mathrm{d} \text { divided in } 2-3 \text { doses/ } \\
\text { day }^{2} \text { ) }\end{array}$ & $\begin{array}{l}\text { Decreases palpitations and tachycardia } \\
\text { Consider if patient has symptomatic tachycardia }\end{array}$ & $\begin{array}{l}\text { Bronchospasm } \\
\text { Hypoglycemia } \\
\text { Bradycardia }\end{array}$ \\
\hline $\begin{array}{l}\text { Propylthiouracil }{ }^{7}(5-7 \mathrm{mg} / \mathrm{kg} / \mathrm{d} \text { in } \\
\text { divided doses every } 8 \mathrm{hr}^{2} \text { ) }\end{array}$ & $\begin{array}{l}\text { Decreases conversion of thyroxine }\left(\mathrm{T}_{4}\right) \text { to triiodothyronine }\left(\mathrm{T}_{3}\right) \\
\text { Consider in addition to beta-blockers in severely symptomatic patients }\end{array}$ & $\begin{array}{l}\text { Adverse drug reactions } \\
\text { (eg, liver dysfunction, } \\
\text { agranulocytosis, rash, } \\
\text { joint pain) }\end{array}$ \\
\hline $\begin{array}{l}\text { Prednisone } 7,13 \text { (case reported of } \\
\text { prednisone } 2.8 \mathrm{mg} / \mathrm{kg} / \mathrm{d} \text { divided } \mathrm{q} \\
6 \mathrm{hr} \text { being given }{ }^{7} \text { ) }\end{array}$ & $\begin{array}{l}\text { Decreases conversion of } T_{4} \text { to } T_{3} \\
\text { Consider in addition to beta-blocker in severely symptomatic patients }\end{array}$ & $\begin{array}{l}\text { Adrenal suppression and } \\
\text { Cushing syndrome with } \\
\text { long-term use }\end{array}$ \\
\hline $\begin{array}{l}\text { Sodium ipodate } \mathrm{e}^{9,13} \text { (case reported of } \\
\text { sodium ipodate [Oragrafin] } 3 \mathrm{~g} / 1.7 \mathrm{~m}^{2} \\
\text { being given as a single dose }{ }^{9} \text { ) }\end{array}$ & $\begin{array}{l}\text { Decreases conversion of } T_{4} \text { to } T_{3} \\
\text { Consider in addition to beta-blockers in severely symptomatic patients }\end{array}$ & $\begin{array}{l}\text { Allergic reaction in } \\
\text { people with iodine } \\
\text { sensitivity }\end{array}$ \\
\hline Charcoal hemoperfusion ${ }^{21}$ & $\begin{array}{c}\text { Extracts excess } \mathrm{T}_{4} \\
\text { Consider only in cases of severe thyrotoxicosis with significant cardiac or } \\
\text { neurologic symptoms }\end{array}$ & Invasive procedure \\
\hline Plasmapheresis ${ }^{16}$ & $\begin{array}{c}\text { Extracts excess } \mathrm{T}_{4} \\
\text { Consider only in extreme cases of severe thyrotoxicosis with significant } \\
\text { cardiac or neurologic symptoms }\end{array}$ & Invasive procedure \\
\hline
\end{tabular}


underlying cardiac conditions such as pre-existing arrhythmias.

Supportive therapy, including acetaminophen for fever and beta-blockers for tachycardia, can be useful once symptoms appear. The potential benefits of administration of antithyroid medications (such as propylthiouracil or prednisone) or invasive procedures (such as charcoal hemoperfusion or plasmapheresis) must be balanced against the potential risks, and such modalities should therefore be considered only in cases of extreme thyrotoxicosis (see Table 2).

\section{CONCLUSION}

Levothyroxine is a common medication that can be attractive to young children as the pills are colourful and palatable. Levothyroxine overdose can result in significant complications, including seizures and arrhythmias, both of which should be monitored for. However, as our case illustrates, massive ingestion of levothyroxine in children typically follows a benign course.

Competing interests: None declared.

\section{REFERENCES}

1. Canaris GJ, Manowitz NR, Mayor G, et al. The Colorado thyroid disease prevalence study. Arch Intern Med 2000;160: 526-34, doi:10.1001/archinte.160.4.526.

2. Pediatric Lexi-Drugs ONLINE. Hudson (OH): American Pharmaceutical Association; 2010.

3. Bronstein AC, Spyker DA, Cantilena LR Jr, et al. 2008 annual report of the American Association of Poison Control Centers' National Poison Data System (NPDS): 26th annual report. Clin Toxicol (Phila) 2009;47:911-1084, doi:10.3109/ 15563650903438566.

4. Gorman RL, Chamberlain JM, Rose SR, et al. Massive levothyroxine overdose: high anxiety-low toxicity. Pediatrics 1988;82:666-9.

5. Lewander WJ, Lacouture PG, Silva JE, et al. Acute thyroxine ingestion in pediatric patients. Pediatrics 1989;84: $262-5$.
6. Willgerodt H, Keller E, Sorger D, et al. Acute ingestion of thyroxine and triiodothyronine in young children. Eur 7 Pediatr 2003;162:639-41, doi:10.1007/s00431-003-1263-2.

7. Lehrner LM, Weir MR. Acute ingestions of thyroid hormones. Pediatrics 1984;73:313-7.

8. Roesch C, Becker PG, Sklar S. Management of a child with acute thyroxine ingestion. Ann Emerg Med 1985;14:1114-5, doi:10.1016/S0196-0644(85)80935-5.

9. Berkner PD, Starkman H, Person N. Acute L-thyroxine overdose; therapy with sodium ipodate: evaluation of clinical and physiologic parameters. 7 Emerg Med 1991;9:129-31, doi:10.1016/0736-4679(91)90317-9.

10. Litovitz TL, White JD. Levothyroxine ingestions in children: an analysis of 78 cases. Am 7 Emerg Med 1985;3: 297-300, doi:10.1016/0735-6757(85)90050-6.

11. Tenenbein $M$, Dean HJ. Benign course after massive levothyroxine ingestion. Pediatr Emerg Care 1986;2:15-7, doi:10.1097/00006565-198603000-00004.

12. Tsutaoka BT, Kim S, Santucci S. Seizure in a child after an acute ingestion of levothyroxine. Pediatr Emerg Care 2005; 21:857-9, doi:10.1097/01.pec.0000190240.81222.9a.

13. Shilo L, Kovatz S, Hadari R, et al. Massive thyroid hormone overdose: kinetics, clinical manifestations and management. Isr Med Assoc 7 2002;4:298-9.

14. Matthews SJ. Acute thyroxine overdosage: two cases of parasuicide. Ulster Med $\mathcal{F}$ 1993;62:170-3.

15. Kulig K, Golightly LK, Rumack BH. Levothyroxine overdose associated with seizures in a young child. FAMA 1985; 254:2109-10, doi:10.1001/jama.254.15.2109.

16. Binimelis J, Bassas L, Marruecos L, et al. Massive thyroxine intoxication: evaluation of plasma extraction. Intensive Care Med 1987;13:33-8, doi:10.1007/BF00263555.

17. Ioos V, Das V, Maury E, et al. A thyrotoxicosis outbreak due to dietary pills in Paris. Ther Clin Risk Manag 2008;4:1375-9.

18. Tunget CL, Clark RF, Turchen SG, et al. Raising the decontamination level for thyroid hormone ingestions. Am 7 Emerg Med 1995;13:9-13, doi:10.1016/0735-6757(95)90231$\underline{7}$.

19. Chyka PA, Seger D, Krenzelok EP, et al. Position paper: single-dose activated charcoal. Clin Toxicol (Phila) 2005;43: 61-87.

20. Vale JA, Kulig K. Position paper: gastric lavage. 7 Toxicol Clin Toxicol 2004;42:933-43, doi:10.1081/CLT-200045006.

21. Kreisner E, Lutzky M, Gross JL. Charcoal hemoperfusion in the treatment of levothyroxine intoxication. Thyroid 2010;20: 209-12, doi:10.1089/thy.2009.0054. 